\title{
Mesothelioma risk after 40 years since first exposure to asbestos: a pooled analysis
}

\author{
A Reid, ${ }^{1} \mathrm{~N}$ H de Klerk, ${ }^{2,3}$ C Magnani, ${ }_{1}^{4}$ D Ferrante, ${ }^{4} \mathrm{G}$ Berry, ${ }^{5}$ A W Musk, ${ }^{2}$ E Merler ${ }^{6}$
}

- Additional material is published online only. To view please visit the journal online (http://dx.doi.org/10.1136/ thoraxjnl-2013-204161).

${ }^{1}$ School of Public Health, Curtin University, Bentley, Western Australia

${ }^{2}$ School of Population Health, The University of Western Australia, Crawley, Western Australia

${ }^{3}$ The Telethon Institute for Child Health Research and the Centre for Child Health Research, The University of Western Australia, Crawley, Western Australia ${ }^{4}$ Cancer Epidemiology Unit, CPO Piemonte and Department of Translational Medicine of the University of Eastern Piedmont, Novara, Italy ${ }^{5}$ The School of Public Health, University of Sydney, Sydney, Australia

${ }^{6}$ Venetian Mesothelioma Registry, Occupational Health Unit, Local Health Authority of Padua, Padua, Italy

\section{Correspondence to} Dr Alison Reid, School of Public Health, Curtin University, Kent Street, Bentley, WA 6102, Western Australia; alison.reid@curtin.edu.au

Received 9 July 2013 Revised 16 April 2014 Accepted 22 April 2014 Published Online First 19 May 2014

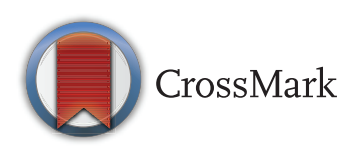

To cite: Reid A, de Klerk NH, Magnani $\mathrm{C}$, et al. Thorax 2014;69:843-850.

\section{ABSTRACT}

Background The risk of malignant mesothelioma (MM) increases proportionally to the cumulative exposure, and to the 3rd or 4th power of time since first exposed, to asbestos. However, little is known about the risk of MM after more than 40 years since first exposure because most epidemiological studies do not have follow-up for sufficient periods of time.

Methods The data from six cohort studies of exposed workers and two cohorts with residential exposure have been pooled. A nested case control design matched cases and controls on calendar period and age. Conditional logistic regression modelled the relationship between time since first exposure and risk of MM.

Results The combined data consisted of 22048 people with asbestos exposure (5769 women), 707 cases of pleural MM (165 in women) and 155 cases of peritoneal MM (32 in women). Median time since first exposure for pleural MM cases was 38.4 years (IQR 31.3-45.3). Median duration of exposure for pleural MM cases was 3.75 years (IQR 0.7-18.2). The rate and risk of pleural MM increased until 45 years following first exposure and then appeared to increase at a slower power of time since first exposure. The rate of increase in peritoneal MM over the 10-50 years since first exposure continued to increase.

Conclusions Exposure to asbestos confers a long-term risk of developing pleural and peritoneal mesothelioma which increases following cessation of exposure. While the rate of increase appears to start to level out after 40-50 years no one survives long enough for the excess risk to disappear.

\section{INTRODUCTION}

Rates of malignant mesothelioma (MM) have been shown to increase proportionally to cumulative exposure to asbestos and increase with the third to fourth power of time since first exposure to asbestos, when based on observations of 20-40 years latency. ${ }^{1}$ Little is known about the risk of mesothelioma after more than 40 years following first exposure because most epidemiological studies do not have follow-up for such long periods of time.

Other work has suggested that the increasing risk of mesothelioma observed over the first 2030 years following first exposure to asbestos may flatten out after more than 40 years since first exposure. Within the Eternit workers cohort the rate of pleural MM increased up to 40 years following first exposure and plateaued thereafter, whereas peritoneal MM showed a continuing increase. $^{2}$ Among female gas mask workers exposed to crocidolite no cases of MM arose more
Key messages

What is the key question?

- Does the risk of mesothelioma continue to increase after more than 40 years since first exposure to asbestos?

What is the bottom line?

- There is evidence that the rate of increase in the incidence for pleural mesothelioma reduces at about 45 years since first exposure while peritoneal mesothelioma continues to increase.

\section{Why read on?}

- This question is examined in men and women and by type and source of asbestos exposure among six occupationally and two environmentally exposed international cohort studies with long-term follow-up.

than 51 years after first exposure. ${ }^{3}$ Among Turin textile workers a reduction of the MM rate was observed. $^{4}$ Similarly, the overall rate of $\mathrm{MM}$ appeared to level off after 50 years following first exposure in the Wittenoom workers, ${ }^{5}$ and this was in pleural and peritoneal MM. ${ }^{6}$ Among the former residents of Wittenoom (those who did not work for the asbestos company), high rates of pleural mesothelioma have been observed. These were greatest among those with more than 40 years since first exposure; 165 per 100000 women and 351 per 100000 men. $^{7}$

The aim of this study was to determine if the risk of malignant pleural and peritoneal MM declines after more than 40 years following first exposure to asbestos. Data from six cohort studies of occupationally exposed workers and two cohort studies of people exposed paraoccupationally and from their general environment was pooled in order to document the rate of $\mathrm{MM}$ after $>40$ years from first exposure.

\section{METHODS}

Participants came from six occupational cohort studies (five from Italy-Casale Monferrato Eternit workers, ${ }^{8}$ amosite factory workers from Molina di Ledro, Trento ${ }^{10}$ and three railway carriage construction and maintenance workers' cohorts ${ }^{11}$ ) and one from Australia (Wittenoom crocidolite miners and millers ${ }^{12}$ ), and two cohorts with general environmental asbestos exposure (one Australian- 
Wittenoom residents) ${ }^{13}$ and one Italian (wives of Eternit asbestos cement factory workers ${ }^{14}$ ) (see online supplementary file).

\section{Follow-up and case ascertainment}

In Italy, vital status and cause of death was ascertained from the local municipality offices which provided, as appropriate: vital status or date and place of death or the new address for those who moved to another municipality. The cause of death was provided from the local health authority offices corresponding to the municipality where death occurred. Causes of death were coded according to International Classification of Diseases volume 9. ${ }^{15} \mathrm{~A}$ national mesothelioma epidemiological surveillance system operates in Italy. Based on regional registries this system is responsible for the identification of new cases and investigation into the sources of asbestos exposure. The data from the two regions presented in this study (Piedmont and Veneto) has been extended so that retrospective cases were also included. Incident cases were obtained to the end of $2008 .{ }^{16}$ All persons contributed person-years at risk to the study until their latest date of observation.

Follow-up of the Wittenoom cohorts occurs passively through linkage to national and state cancer and mortality registers and/ or participation in a cancer prevention programme. ${ }^{17}$ Incident cases of $\mathrm{MM}$ in former workers and residents of Wittenoom were obtained from the Western Australian (WA) mesothelioma registry. ${ }^{18}$ For those no longer resident in WA incident cases were obtained from the National Cancer Clearing House and the Australian Mesothelioma Register. ${ }^{19}$ Deaths information was obtained from the WA Registrar General's mortality database and the National Death Index. Some additional mesotheliomas have been identified in the follow-up of about 300 migrant workers who returned to Italy.

Deaths and mesothelioma incidence were obtained to the end of 2007. Workers and residents who had not developed MM and who have not been lost to follow-up were censored at their date of death, date they turned 85 years or 31 December 2007, whichever was earliest. Workers and residents who had been lost to follow-up were censored at the date they were last known to be alive.

\section{Data pooling and preparation for analysis}

The latest time since first exposure was derived by subtracting the date of first exposure to asbestos from the date of diagnosis with $\mathrm{MM}$ or the date of last follow-up (if still alive). For the occupational cohorts the date of first exposure was the date they started work. Date of first exposure for the Wittenoom residents was the date they arrived in Wittenoom. Date of first exposure for the Eternit wives was either the date of their marriage (if the husband was already working at the Eternit plant) or the date the husband started work at the plant, if this was after the date of their marriage. Duration of exposure was the duration of employment for those in the occupational cohorts. For the Eternit wives duration of exposure was the time that the husband worked at the Eternit plant and for the Wittenoom residents it was the period that they lived at Wittenoom.

The variables were renamed and recoded in each separate data set to make them consistent and then combined. To enable the nested case-control design and to allow for the timedependent nature of time since first exposure and duration of exposure, multiple records were generated for each cohort member for each year of their follow-up giving 1 year increments of age, 5 year increments of calendar period and 1 year increments of time since first exposure and duration of exposure. Matching strata were then defined based on age and calendar period with cases matched with a maximum of 150 controls each. The controls were chosen randomly from the cohort members who were at risk at the 'failure time' (ie, the same combination of age and calendar period) of the case, with all time variables defined as at that failure time. Controls may have been matched to more than one case. Cases were eligible to be a control for any case occurring before they were themselves diagnosed with or died from MM. Pleural and peritoneal MM were matched separately. Where there were fewer than 150 controls per case, the number allocated automatically by the matching procedure was accepted.

\section{Statistical analysis}

The unmatched rates of pleural and peritoneal MM for 5 year categories of time since first exposure and duration of exposure were created by dividing the number of cases by the number of person years in each 5 year category of time since first exposure and duration of exposure and multiplying by 10000 .

Conditional logistic regression examined the relationship between time since first exposure and pleural and peritoneal MM. A clearance term (as used in Berry $2012^{6}$ ) was included in the models to examine changes in the time exponent (power of time since first exposure). The time exponent was also examined by duration of exposure. Models were adjusted for sex. The source of asbestos exposure (mine and mill, asbestos cement factory, amosite factory, environmental and railway stock exposure) and the type of asbestos exposure (crocidolite, amosite and mixed (chrysotile and crocidolite) were also examined. Likelihood ratio testing was used to determine which variables were included in the final model depending on whether it was statistically significant $(p<0.05)$ after introduction to the model. All statistical analysis and data manipulation was undertaken in Stata V.12. ${ }^{20}$

\section{RESULTS}

Combining all cohort data sets gave a total population of 22048 (5769 women) asbestos exposed persons (table 1). Median age at first exposure of all cohort members was in the early to mid-20s excepting Wittenoom residents who were aged 11 years. Eternit workers and wives were exposed to a mixture of asbestos fibre types, largely chrysotile and crocidolite. Railway stock workers were exposed predominantly to crocidolite and to chrysotile to a lesser extent. The amosite factory workers were exposed solely to amosite while Wittenoom workers and residents were exposed only to crocidolite.

All of the cohort studies reported cases of MM of the pleura and peritoneum (table 2). In total there were 707 (542 men) cases of pleural MM and 155 (123 men) cases of peritoneal MM. Pleural MM was 4.6 times more common than peritoneal MM. Wittenoom workers and residents contributed $56 \%$ of pleural and 39\% of peritoneal cases. Eighty-three per cent of the pleural cases and $72 \%$ of the peritoneal cases were ascertained as incident cases through cancer registries, rather than from death certificates. The median duration of exposure was longer in the Italian cohorts (7-28 years) than either the Wittenoom workers' (8 months) or residents' (1.5 years), and over all the cohorts was 3.7 years. The median latency (the period between time since first asbestos exposure and pleural MM diagnosis) over all the cohorts was 38.4 years and was shorter for the Wittenoom workers (35 years) than any of the other groups.

Over all cohorts and men and women together 44\% of pleural $\mathrm{MM}$ and $54 \%$ of peritoneal MM occurred after 40 years or more since first exposure to asbestos (table 3). Women 
Table 1 Characteristics of cohort studies

\begin{tabular}{|c|c|c|c|c|c|c|c|c|c|}
\hline Cohort & $\begin{array}{l}N \\
16279 \\
(m) \\
5769(f)\end{array}$ & Definition & $\begin{array}{l}\text { Period of } \\
\text { operation }\end{array}$ & Type of asbestos & $\begin{array}{l}\text { How cohort was } \\
\text { established }\end{array}$ & $\begin{array}{l}\text { Exposure } \\
\text { measurements }\end{array}$ & Start of follow-up & End of follow up & $\begin{array}{l}\text { Median age of first } \\
\text { exposure Years (IQR) }\end{array}$ \\
\hline Wittenoom Workers & $\begin{array}{l}6489(m) \\
421(f)\end{array}$ & $\begin{array}{l}\text { Asbestos mine and mill } \\
\text { workers }\end{array}$ & 1937-1966 & Crocidolite & Employment records & $\begin{array}{l}\mathrm{f} / \mathrm{ml} \text {-year } \\
\text { time since first } \\
\text { exposure }\end{array}$ & Start of employment & 31 December 2007 & $27.6(22.6-35.3)$ \\
\hline Wittenoom Residents & $\begin{array}{l}2206(m) \\
2615(f)\end{array}$ & Resident of Wittenoom & 1937-1992 & Crocidolite & Public records & $\begin{array}{l}\mathrm{f} / \mathrm{ml} \text {-year } \\
\text { time since first } \\
\text { exposure }\end{array}$ & Start of residence & 31 December 2007 & $11.3(2.6-27.3)$ \\
\hline $\begin{array}{l}\text { Eternit Workers, Casale } \\
\text { Monferrato }\end{array}$ & $\begin{array}{l}2657(\mathrm{~m}) \\
777(\mathrm{f})\end{array}$ & $\begin{array}{l}\text { Asbestos cement factory } \\
\text { workers }\end{array}$ & 1907-1986 & $\begin{array}{l}\text { Crocidolite and } \\
\text { chrysotile }\end{array}$ & Employment records & $\begin{array}{l}\text { Duration of } \\
\text { employment } \\
\text { Time since first } \\
\text { exposure }\end{array}$ & Start of employment & 31 December 2008 & $27.6(21.4-35.3)$ \\
\hline $\begin{array}{l}\text { Eternit Wives, Casale } \\
\text { Monferrato }\end{array}$ & 1779 (f) & $\begin{array}{l}\text { Wives of Eternit factory } \\
\text { workers }\end{array}$ & 1921-1986 & $\begin{array}{l}\text { Crocidolite and } \\
\text { chrysotile }\end{array}$ & Public records & $\begin{array}{l}\text { Duration } \\
\text { Time since first } \\
\text { exposure }\end{array}$ & $\begin{array}{l}\text { Marriage or start of } \\
\text { husband's employment }\end{array}$ & 31 December 2008 & $29.3(24.1-36.0)$ \\
\hline $\begin{array}{l}\text { Amosite factory (Collotta } \\
\& \text { CIS), Molina di Ledro }\end{array}$ & $\begin{array}{l}248(\mathrm{~m}) \\
161(\mathrm{f})\end{array}$ & Amosite factory workers & 1919-1978 & Amosite & $\begin{array}{l}\text { Recall of workers and } \\
\text { various public records }\end{array}$ & $\begin{array}{l}\text { Duration of } \\
\text { employment } \\
\text { Time since first } \\
\text { exposure }\end{array}$ & Start of employment & 31 December 2007 & $24.7(17.4-36.3)$ \\
\hline $\begin{array}{l}\text { Officine Meccaniche } \\
\text { Stanga, Padua }\end{array}$ & $\begin{array}{l}1847(\mathrm{~m}) \\
6(\mathrm{f})\end{array}$ & $\begin{array}{l}\text { Construction, repair and } \\
\text { renovation of railway stock }\end{array}$ & 1956-1982 & $\begin{array}{l}\text { Crocidolite mainly, } \\
\text { and chrysotile }\end{array}$ & Employment records & $\begin{array}{l}\text { Duration of } \\
\text { employment } \\
\text { Time since first } \\
\text { exposure }\end{array}$ & $\begin{array}{l}1956 \text { or start of } \\
\text { employment if later }\end{array}$ & 15 September 2007 & $25.5(21.0-32.5)$ \\
\hline $\begin{array}{l}\text { Officina Meccanica } \\
\text { Cittadella, province of } \\
\text { Padua }\end{array}$ & $\begin{array}{l}1125(\mathrm{~m}) \\
10(\mathrm{f})\end{array}$ & $\begin{array}{l}\text { Repair and renovation of } \\
\text { railway stock }\end{array}$ & 1956-1989 & $\begin{array}{l}\text { Crocidolite mainly, } \\
\text { and chrysotile }\end{array}$ & Employment records & $\begin{array}{l}\text { Duration of } \\
\text { employment } \\
\text { Time since first } \\
\text { exposure }\end{array}$ & $\begin{array}{l}1956 \text { or start of } \\
\text { employment if later }\end{array}$ & 15 September 2007 & $22.6(17.8-30.9)$ \\
\hline $\begin{array}{l}\text { Main repair workshop } \\
\text { Railway Service, Vicenza }\end{array}$ & $\begin{array}{l}1706(\mathrm{~m}) \\
0\end{array}$ & $\begin{array}{l}\text { Repair and renovation of } \\
\text { railway stock }\end{array}$ & 1956-1988 & $\begin{array}{l}\text { Crocidolite mainly, } \\
\text { and chrysotile }\end{array}$ & Employment records & $\begin{array}{l}\text { Duration of } \\
\text { employment } \\
\text { Time since first } \\
\text { exposure }\end{array}$ & $\begin{array}{l}1956 \text { or start of } \\
\text { employment if later }\end{array}$ & 15 September 2007 & $25.8(22.3-30.0)$ \\
\hline
\end{tabular}


Table 2 Exposure characteristics of cases

\begin{tabular}{|c|c|c|c|c|c|c|c|}
\hline & $\begin{array}{l}\text { Availability } \\
\text { of MM } \\
\text { incidence }\end{array}$ & $\begin{array}{l}\text { Pleural MM } \\
\mathrm{N}=542(\mathrm{~m}) \\
\mathrm{N}=165 \text { (f) }\end{array}$ & $\begin{array}{l}\text { Incident } \\
\text { cases of } \\
\text { pleural MM } \\
587(83 \%) \\
\mathrm{N}(\%)\end{array}$ & $\begin{array}{l}\text { Peritoneal } \\
\text { MM } \\
N=123(\mathrm{~m}) \\
\mathrm{N}=32 \text { (f) }\end{array}$ & $\begin{array}{l}\text { Incident } \\
\text { cases of } \\
\text { Peritoneal } \\
\text { MM } \\
111(72 \%) \\
\mathrm{N}(\%)\end{array}$ & $\begin{array}{l}\text { Pleural MM } \\
\text { median } \\
\text { duration } \\
\text { of exposure } \\
\text { (years) (IQR) } \\
3.75(0.67-18.2)\end{array}$ & $\begin{array}{l}\text { Pleural } \mathrm{mm} \\
\text { median time } \\
\text { since first } \\
\text { exposure } \\
\text { (years) (IQR) } \\
38.4(31.3-45.3 \text { ) }\end{array}$ \\
\hline Wittenoom Workers & 1960-2007 & $\begin{array}{l}293(\mathrm{~m}) \\
14(\mathrm{f})\end{array}$ & $297(97)$ & $55(m)$ & $52(95)$ & $0.65(0.28-1.79)$ & $35.3(28.9-41.6)$ \\
\hline Wittenoom Residents & 1960-2007 & $\begin{array}{l}49(m) \\
43(f)\end{array}$ & 91 (99) & $\begin{array}{l}5(\mathrm{~m}) \\
1 \text { (f) }\end{array}$ & $6(100)$ & $1.50(0.50-3.17)$ & $40.9(35.6-45.7)$ \\
\hline Eternit Workers & 1990-2008 & $\begin{array}{l}126(\mathrm{~m}) \\
59(\mathrm{f})\end{array}$ & $89(48)$ & $\begin{array}{l}54(m) \\
25(f)\end{array}$ & $42(53)$ & $21.0(9.46-28.2)$ & $39.5(31.8-47.7)$ \\
\hline Eternit Wives & 1990-2008 & $41(f)$ & $30(83)$ & $3(f)$ & $1(33)$ & $16.2(7.76-24.1)$ & $42.2(34.4-46.7)$ \\
\hline Amosite factory & 1977-2008 & $\begin{array}{l}3(\mathrm{~m}) \\
7(\mathrm{f})\end{array}$ & $10(100)$ & $\begin{array}{l}1(\mathrm{~m}) \\
2(\mathrm{f})\end{array}$ & $3(100)$ & $7.3(1.59-19.0)$ & $47.2(40.3-56.3)$ \\
\hline Officina Meccanica Stanga & 1987-2008 & $\begin{array}{l}44(m) \\
1(f)\end{array}$ & $43(96)$ & $3(\mathrm{~m})$ & $3(100)$ & $28.3(13.6-34.5)$ & $44.3(34.2-50.1)$ \\
\hline Officina Meccanica Cittadella & 1987-2008 & $10(\mathrm{~m})$ & $10(100)$ & $1(\mathrm{~m})$ & $1(100)$ & $20.6(11.4-31.3)$ & $41.8(36.3-47.9)$ \\
\hline $\begin{array}{l}\text { Main repair workshop, } \\
\text { Vicenza }\end{array}$ & 1987-2008 & $17(\mathrm{~m})$ & $17(100)$ & $4(\mathrm{~m})$ & $3(75)$ & $21.0(14.0-35.0)$ & $45.3(37.7-51.7)$ \\
\hline
\end{tabular}

had a longer latency than men with $81 \%$ of peritoneal MM occurring in women after 40 years since first exposure compared with $47 \%$ in men and 60\% of pleural MM occurring after 40 years in women compared with $40 \%$ in men. There were two cases of MM that developed within 10 years of first exposure, one pleural and one peritoneal MM, both in Eternit workers, 7.6 years and 7.2 years, respectively.

The unadjusted rate of pleural mesothelioma per 10000 person years at risk, on a log scale, across all cohorts and both sexes by 5 year categories of time since first exposure and duration of exposure showed that the relationship between MM and time since first exposure has a tendency towards flattening out as time since first exposure goes beyond 40 years and 50 years (figure 1 ). For peritoneal $\mathrm{MM}$ the rate continued to increase as time since first exposure increased beyond 40 years and 50 years with no tendency towards flattening out (figure 2).

There was no significant effect for clearance in the peritoneal model in contrast to the pleural model $(-0.04)$ (table 4$)$. The effect of clearance in the pleural model is similar to earlier observations. ${ }^{21}$ Mining and milling conferred the greatest risk of pleural and peritoneal MM by source of asbestos exposure. Incidence increases with duration or a transformation of duration of exposure for pleural and peritoneal mesothelioma, and the risk is lower for women than men.
The time exponent was larger for peritoneal mesothelioma (3.21) than pleural mesothelioma (2.81) (table 4).The models were repeated adjusting for varying durations of exposure. The time exponent changed by duration of exposure for pleural and peritoneal mesothelioma, but it was not statistically significant (data not shown).

The adjusted log risk of pleural mesothelioma increases until about 45 years since first exposure and then shows a tendency to start to flatten out (figure 3). This flattening suggests that after 45 years the $\mathrm{MM}$ rate does not increase as quickly as a power of time since first exposure. The adjusted log risk for peritoneal $\mathrm{MM}$ increased proportionally with log time since first exposure (figure 4) and in contrast to pleural MM there was no evidence of any flattening out.

The risk of peritoneal mesothelioma increases moderately with longer duration of exposure (figure 5).

\section{DISCUSSION}

In this study the data from six occupational and two residential cohort studies has been pooled to examine the rates of MM after more than 40 years following first exposure to asbestos. For pleural MM, the graph of the relationship of rates with time since first exposure starts to flatten at around 45 years following first exposure, suggesting that the rate of MM does not

Table 3 Cases of MM in men and women by categories of time since first exposure

\begin{tabular}{|c|c|c|c|c|c|c|}
\hline \multirow[b]{2}{*}{ Time since first exposure } & \multicolumn{2}{|l|}{ Men } & \multicolumn{2}{|l|}{ Women } & \multicolumn{2}{|l|}{ Total } \\
\hline & $\begin{array}{l}\text { Pleural } \\
\mathrm{N} \%\end{array}$ & $\begin{array}{l}\text { Peritoneal } \\
\mathrm{N} \%\end{array}$ & $\begin{array}{l}\text { Pleural } \\
\mathrm{N} \%\end{array}$ & $\begin{array}{l}\text { Peritoneal } \\
\mathrm{N} \%\end{array}$ & Pleural & Peritoneal \\
\hline$\leq 10$ years & $1(0.18)$ & 0 & 0 & $1(3.1)$ & $1(0.14)$ & $1(0.6)$ \\
\hline $10-\leq 20$ years & $28(5.17)$ & $1(0.81)$ & $5(3.0)$ & 0 & $33(4.7)$ & $1(0.6)$ \\
\hline $20-\leq 30$ years & $101(18.6)$ & $15(12.2)$ & $13(7.9)$ & $2(6.3)$ & $114(16.1)$ & $17(11.0)$ \\
\hline $30-\leq 40$ years & $197(36.3)$ & $49(39.8)$ & $48(29.1)$ & $3(9.4)$ & $245(34.6)$ & $52(33.5)$ \\
\hline $40-\leq 50$ years & $161(29.7)$ & $42(34.2)$ & $59(35.8)$ & $6(18.8)$ & $220(31.1)$ & $48(31.0)$ \\
\hline $50+$ years & $54(10.0)$ & $16(13.0)$ & $40(24.2)$ & $20(62.5)$ & $94(13.3)$ & $36(23.2)$ \\
\hline Total & 542 & 123 & 165 & 32 & 707 & 155 \\
\hline
\end{tabular}

MM, malignant mesothelioma. 
Figure 1 Rate* of pleural malignant mesothelioma (MM) (log scale) by 5 year categories of time since first exposure and duration of exposure, all cohorts, unmatched.

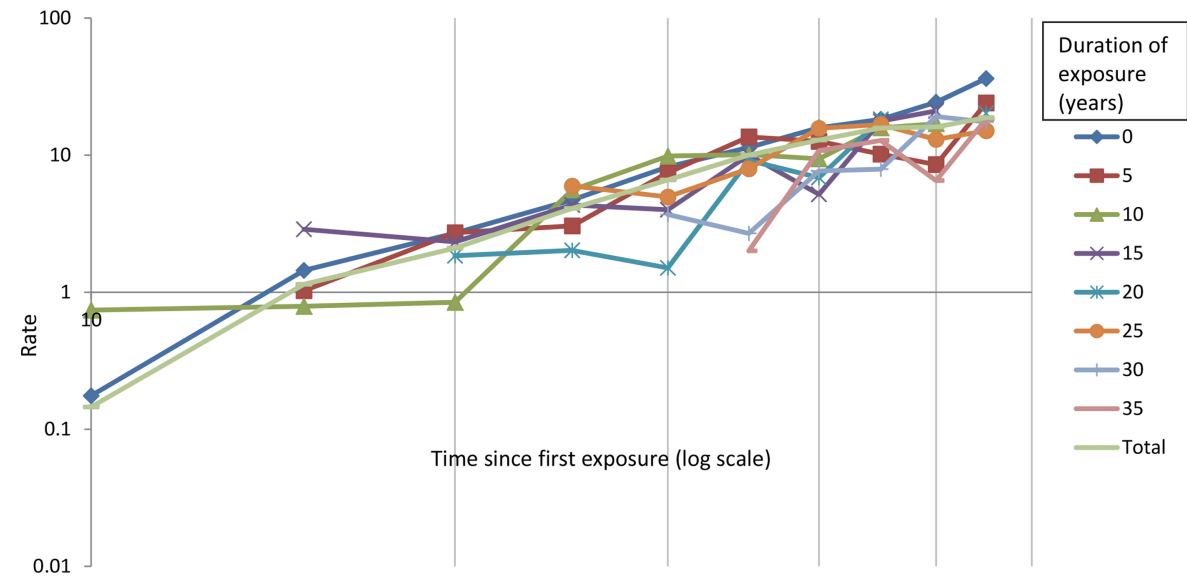

Figure 2 Rate* of peritoneal malignant mesothelioma (MM) (log scale) by 5 year categories of time since first exposure and duration of exposure, all cohorts, unmatched.

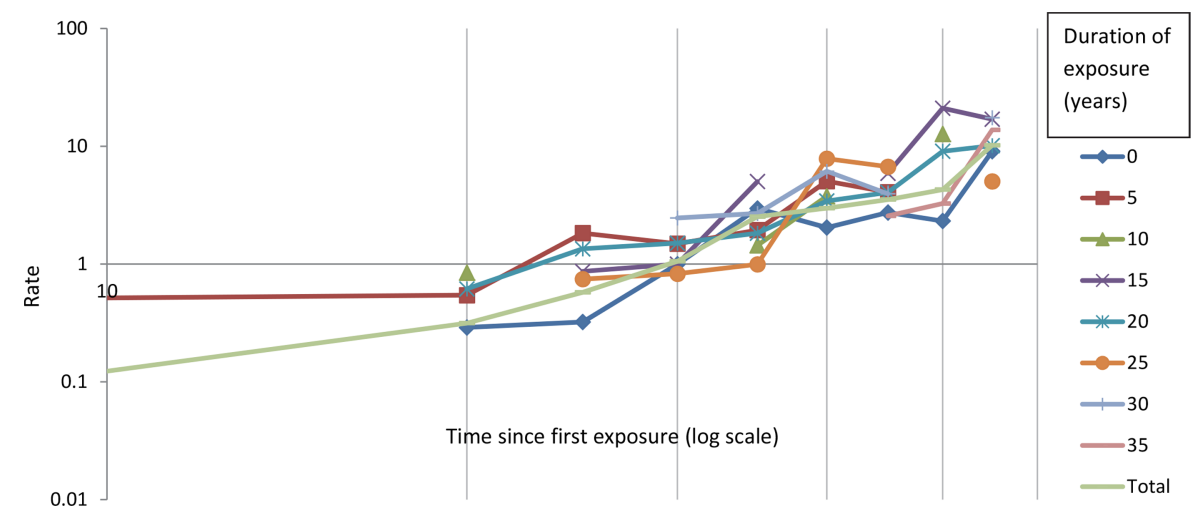

continue to increase as quickly as a power of time since first exposure. Crocidolite conferred the greatest risk of pleural MM compared with amosite and mixed fibres. For peritoneal MM the rate has continued to increase proportionally with time since first exposure and shows no evidence of flattening.

Together the Wittenoom cohorts contributed more pleural MM cases than the other cohorts combined. Duration of exposure was shorter among the Wittenoom cohorts than the Italian cohorts. The cohorts also differed in terms of their intensity of exposure. The Wittenoom, Eternit and Amosite factory workers had large numbers of deaths from asbestosis and from other respiratory causes, but this was not the case for the Wittenoom residents, the Eternit wives or the Railway workers. An increased risk for mesothelioma occurs when a higher lung fibre burden and thus a higher cumulative dose is experienced, as may have occurred in members of the cohorts with excess asbestos-related diseases. Asbestos fibres translocate to the pleural space following interstitial fluid, a process enhanced by chronic inflammation, which is again in relation to the amount of fibres retained in the lungs. ${ }^{22}$

Malignant mesothelioma has traditionally been difficult to diagnose and has often been misclassified as lung cancer. Given the relatively small number of cases of mesothelioma, any potential misclassification may have a substantial impact upon our results. Therefore checks have been periodically carried out among all incident cases to confirm diagnosis. Among the Wittenoom workers' and residents' cohorts incident cases from WA have been pathologically and histologically verified by the WA mesothelioma registry and by an expert panel of pathologists for cases residing outside of WA. Cases of mesothelioma from the area of Casale Monferrato in Italy have been pathologically evaluated and confirmed in two studies. ${ }^{23}$ More
Table 4 Incidence of pleural mesothelioma adjusted for sex, time since first exposure ${ }^{a}$, time since first exposure ${ }^{b}$ duration of exposure $^{\mathrm{a}}$, source of asbestos exposure and crocidolite (707 cases and up to 150 controls per case ( $\min 29: \max 150)$ ) and incidence of peritoneal mesothelioma adjusted for sex, time since first exposure $^{b}$, duration of exposure ${ }^{b}$ and source of asbestos exposure (155 cases and up to 150 controls per case ( $\min 66: \max 150)$ )

\begin{tabular}{|c|c|c|c|}
\hline Variables & Coef. & $95 \% \mathrm{Cl}$ & $p$ Value \\
\hline \multicolumn{4}{|l|}{ Pleural mesothelioma } \\
\hline Sex & -0.41 & -0.63 to 0.18 & $<0.01$ \\
\hline Time since first exposure ${ }^{a}$ & -0.04 & -0.08 to -0.00 & 0.049 \\
\hline Time since first exposure ${ }^{b}$ & 2.81 & 1.50 to 4.13 & $<0.01$ \\
\hline Duration of exposure ${ }^{a}$ & -0.79 & -1.50 to -0.08 & 0.029 \\
\hline Mine or mill & 0.00 & & \\
\hline Asbestos cement factory & -0.06 & -0.50 to 0.39 & 0.798 \\
\hline Amosite factory & -0.73 & -1.49 to 0.02 & 0.058 \\
\hline Railway workers & -1.44 & -1.94 to -0.94 & $<0.01$ \\
\hline Environmental exposure & -0.89 & -1.19 to -0.58 & $<0.01$ \\
\hline Crocidolite & 0.94 & 0.50 to 1.38 & $<0.01$ \\
\hline \multicolumn{4}{|l|}{ Peritoneal mesothelioma } \\
\hline Sex & -0.72 & -1.19 to 0.24 & 0.003 \\
\hline Time since first exposure ${ }^{b}$ & 3.21 & 2.19 to 4.22 & $<0.01$ \\
\hline Duration of exposure ${ }^{b}$ & 0.79 & 0.55 to 1.04 & $<0.01$ \\
\hline Mine or mill & 0.00 & & \\
\hline Asbestos cement factory & -1.06 & -1.67 to -0.46 & $<0.01$ \\
\hline Amosite factory & -2.17 & -3.41 to -0.93 & $<0.01$ \\
\hline Railway workers & -3.83 & -4.75 to -2.91 & $<0.01$ \\
\hline Environmental exposure & -2.56 & -3.45 to -1.66 & $<0.01$ \\
\hline \multicolumn{4}{|c|}{$\begin{array}{l}\text { Time since first exposure } a=\text { time since first exposure }(\lambda \text { (asbestos clearance)). } \\
\text { Time since first exposure } b=\ln \text { (time since first exposure }+1)(k \text { (power)). } \\
\text { Duration of exposure } a=d u r a t i o n \text { of exposure }{ }^{-0.5} \text {. } \\
\text { Duration of exposure } b=\ln (\text { duration of exposure }+0.02)(0.02=1 \text { week). }\end{array}$} \\
\hline
\end{tabular}


Figure 3 Log relative risk of pleural mesothelioma, time since first exposure, adjusted for sex, duration of exposure, asbestos source and crocidolite, 707 cases each matched with up to 150 controls (min 29:max 150).

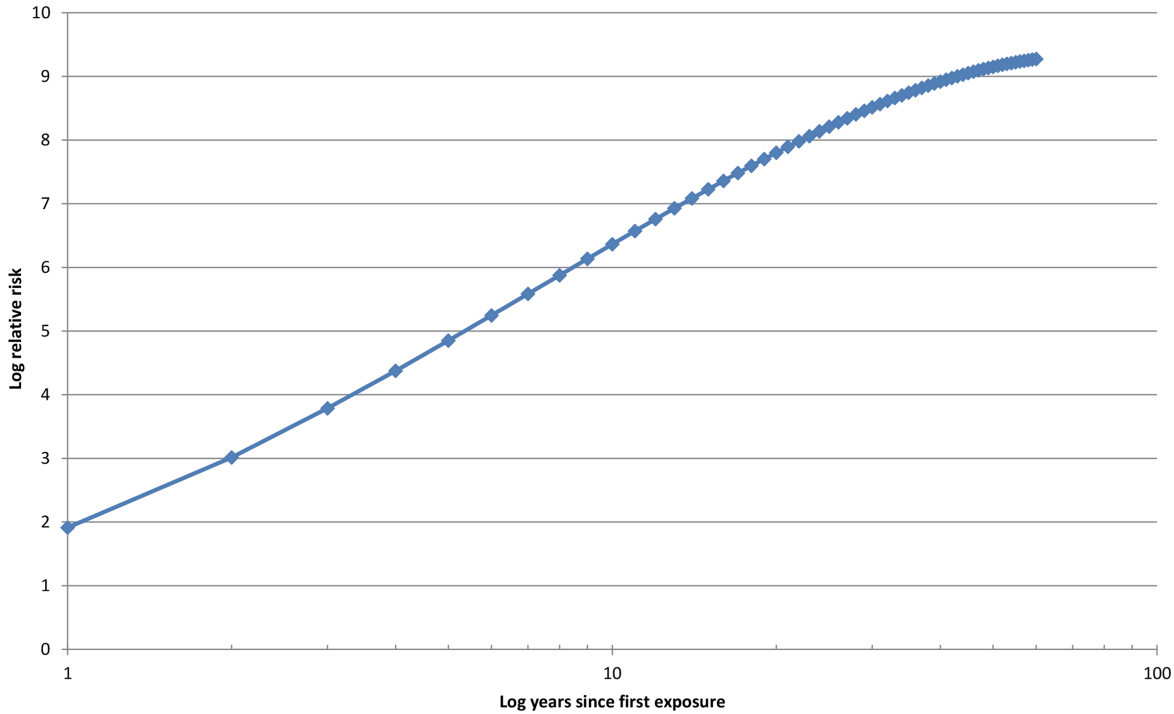

recent studies of the Eternit workers' and wives' cohorts has relied on the diagnostic revision undertaken by the Mesothelioma Registry, where cases must be diagnosed with pathology and immunohistochemistry. ${ }^{8}$ There has been no such systematic effort for the cases reported by death certificate, except for an effort to collect the clinical records: however the results of these earlier studies suggest a reassuring level of diagnostic accuracy. In the region of Veneto (Italy) where the large majority of the railroad factory workers reside, every effort to verify any new diagnosis of mesothelioma with supporting clinical information has occurred since 1984.

This study shows that women tended to have a longer latency period for mesothelioma than men. The women in this study mostly obtained their asbestos exposure from residential or domestic sources which tend to be lower than exposures observed in occupational settings. Lower asbestos exposure has been shown elsewhere to be associated with a longer latency period. ${ }^{25}$ Among the Wittenoom women, those who worked for the asbestos company had a shorter latency period than those who obtained similar cumulative exposure through their residence at Wittenoom ${ }^{26}$ although the Wittenoom workers' latency was shown to be independent of degree of exposure. ${ }^{6}$

Clearance of amphibole fibres has been observed from lung tissues in animal experiments and from lung fibre counts at postmortem among occupationally exposed workers. Rats exposed to crocidolite through inhalation for 6 months showed that $73 \%$ of the fibres had been eliminated 18 months after the last exposure. The amount of chrysotile in the lungs did not increase with continuing exposure by inhalation, which suggests a high elimination rate for chrysotile. ${ }^{27}$ Among crocidolite miners in South Africa, a half-life of 6 years was estimated, ${ }^{28}$ corresponding to an elimination rate of $12 \%$ per annum. ${ }^{29}$ The rate of elimination of the lung burden among female World War II gas mask assemblers, exposed to high amounts of crocidolite over a short space of time, was estimated at $7.5 \%$ per annum. ${ }^{30}$ Clearance per annum of around 9\% was estimated among the Wittenoom workers. $^{21}$ Elimination of asbestos fibres may explain the pattern flattening for pleural mesothelioma where the rate is not increasing as quickly as time to a power. In contrast, for peritoneal mesotheliomas the risk increases more
Figure 4 Log relative risk of peritoneal mesothelioma, time since first exposure, adjusted for sex, duration of exposure, asbestos source and crocidolite, 155 cases matched with up to 150 controls (min 66: $\max$ 150).

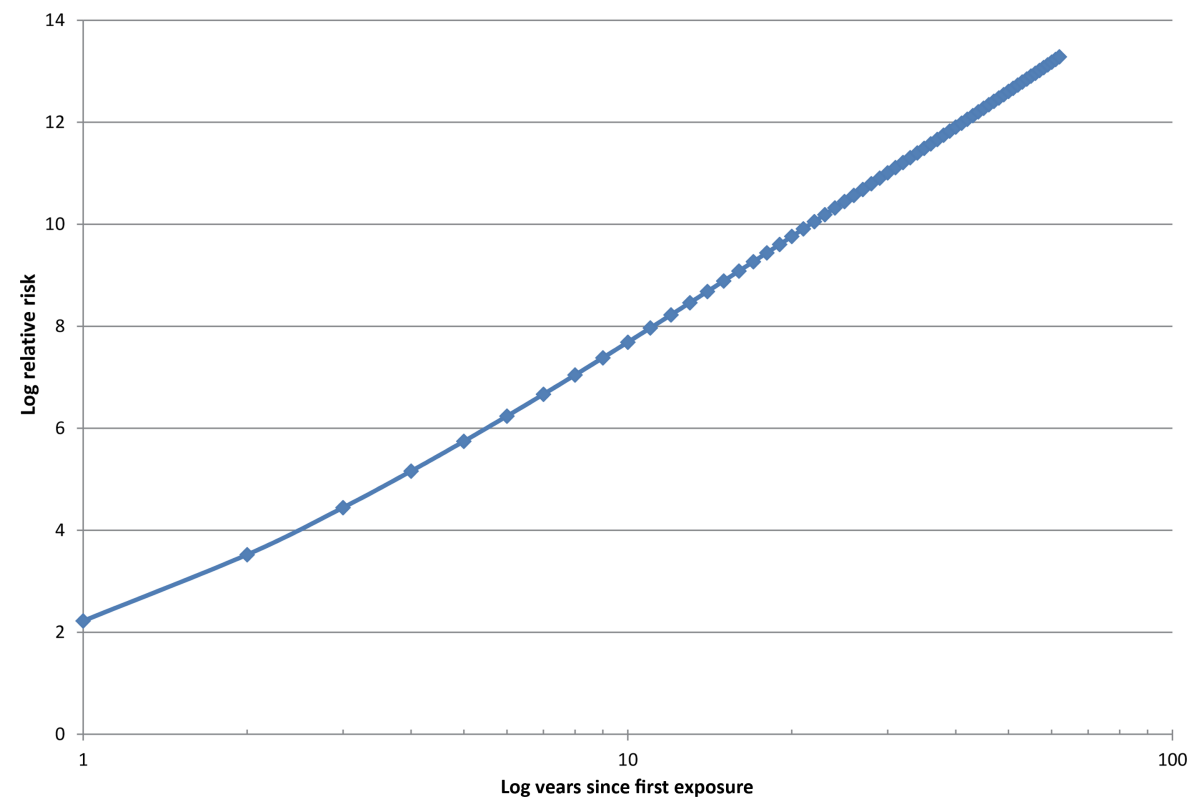


Figure 5 Log relative risk of peritoneal mesothelioma and duration of exposure adjusted for sex, time since first exposure and asbestos source, 155 cases matched with up to 150 controls(min 66:max 150).

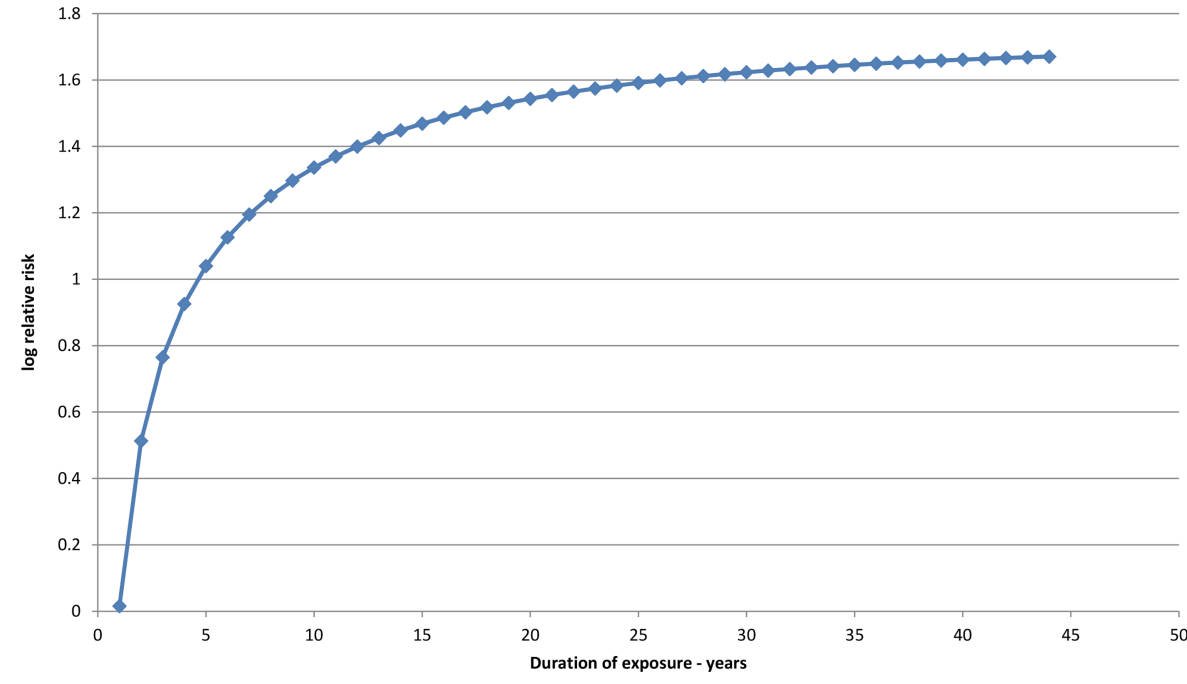

quickly than time to a power, suggesting that elimination of asbestos fibres from the lungs over a long period of time may be of less importance, possibly because of the time pattern of migration of fibres to the peritoneum in the more heavily exposed persons in whom the majority of peritoneal mesotheliomas occur. In the present study we did not find a significant effect for clearance in the peritoneal mesothelioma model.

Reductions in malignant mesothelioma rates have been reported from several countries over recent years. ${ }^{31-33}$ In Norway, mesothelioma rates declined in men from 1.6 per 100000 in 2000-2004 to 1.5 per 100000 in 2005-2009. The rate in women was much lower at 0.3 per 100000 but had not declined. ${ }^{31}$ Similarly, mesothelioma rates in the USA showed a decline from 2005 in men, but no change in the rates for women. These declining rates may reflect the reduction in use of asbestos products in these countries from the 1970s. ${ }^{32} 33$ These declines fit in with what is observed in this present study. We found that the rate of increase in the incidence of pleural mesothelioma reduces while there is no such reduction for peritoneal mesothelioma, supporting that these two neoplasms should be considered separately.

Earlier work reported a lower rate of mesothelioma among those first exposed to asbestos at Wittenoom as children aged $<15$ years (47 per 100000 ) compared with those first exposed aged $>15$ years $(112$ per 100000$){ }^{7}$ More recent work showed that the pleural mesothelioma rate had declined to 34 per 100000 among those first exposed to asbestos aged $<15$ years. ${ }^{34}$ However, those exposed as children have longer to live after exposure and so their lifetime risk, according to this current study, may not be lower than those exposed at older ages. A reduction in increased risk among those with a long latency indicates that the asbestos effect does not occur in the early stages of carcinogenesis.

Exposure to asbestos confers a long-term risk of developing pleural and peritoneal mesothelioma which increases following cessation of exposure despite some fibre clearance. While the rate of increase appears to level out for pleural mesothelioma after $40-50$ years no one survives long enough for the risk to disappear.

Acknowledgements The authors are indebted to many colleagues who have helped in establishing the cohorts and in their follow-up: especially Dr G Parolari, Riva del Garda; Dr G Tessadri, Vicenza; Dr F Gioffrè, Padua; Dr R Bizzotto, Cittadella, Professor M Hobbs, Professor B Armstrong, Dr J Hansen and Dr J McNulty.
Contributors EM, CM and DF provided Italian cohort data and provided advice about their cohorts. AR, NHdK and GB undertook the statistical analysis. All authors helped interpret the analysis and understand the findings. AR wrote the draft manuscript. All authors collaborated on the final manuscript.

Funding National Health and Medical Research Council, Project Grant \#634458 (National Health and Medical Research Council Project Grant \#634458).

Competing interests None.

Ethics approval Western Australian Department of Health HREC.

Provenance and peer review Not commissioned; externally peer reviewed.

\section{REFERENCES}

1 Peto J, Seidman H, Selikoff IJ. Mesothelioma mortality in asbestos workers: implications for models of carcinogenesis and risk assessment. $\mathrm{Br} J$ Cancer 1982:45:124-35

2 Barone-Adesi F, Ferrante D, Bertolotti M, et al. Long-term mortality from pleural and peritoneal cancer after exposure to asbestos: Possible role of asbestos clearance. Int J Cancer 2008;123:912-16.

3 McDonald JC, Harris JM, Berry G. Sixty years on: the price of assembling military gas masks in 1940. Occup Environ Med 2006;63:852-5.

4 Pira E, Pelucchi C, Buffoni $L$, et al. Cancer mortality in a cohort of asbestos textile workers. Br J Cancer 2005;92:580-6.

5 Musk AW, de Klerk NH. Epidemiology of malignant mesothelioma in Australia. Second Heidelberg Thoracic Oncology Symposium; Heidelberg, 2002.

6 Berry G, Reid A, Aboagye-Sarfo P, et al. Malignant mesotheliomas in former miners and millers of crocidolite at Wittenoom (Western Australia) after more than 50 years follow-up. Br J Cancer 2012;106:1016-20

7 Reid $A$, Berry $\mathrm{G}$, de Klerk $\mathrm{N}$, et al. Age and sex differences in malignant mesothelioma after residential exposure to blue asbestos (crocidolite). Chest 2007;131:376-82.

8 Magnani C, Ferrante D, Barone-Adesi F, et al. Cancer risk after cessation of asbestos exposure: a cohort study of Italian asbestos cement workers. Occup Environ Med 2008;65:164-70.

9 Parolari G, Merler E, Riboli E. Cancer mortality in amosite workers. International Symposium on Prevention of Occupational Cancer; Helsinki, Finland: International Labour Organisation, 1982.

10 Parolari G, Merler E, Bertazzi PA, et al. The effects of asbestos exposure of workers of a factory producing insulating materials. 2. Epidemiological study of the causes of mortality. In: Parolari G G G, Criistofolini A, et al, eds. I/ rischio neoplastico da amianto nei luoghi di lavoro e nell'ambiente di vita. Verona: Bi \& Gi Editori, 1987:123-44.

11 Tessari R, Canova C, Simonato L. Indagine epidemiologica sullo stato di salute degl addetti alla produzione e riparazione carrozze ferroviarie: uno studio prospettico in two factories manufacturing and repairing railway rolling stock: a historical prospective study of mortality. Medicina del lavoro 2004;95:381-91.

12 Armstrong BK, de Klerk NH, Musk AW, et al. Mortality in miners and millers of crocidolite in Western Australia. Br J Ind Med 1988:45:5-13.

13 Hansen J, de Klerk NH, Eccles JL, et al. Malignant mesothelioma after environmental exposure to blue asbestos. Int J Cancer 1993:54:578-81. storico di mortalita Epidemiological investigation on the health status of employees 
14 Ferrante D, Bertolotti M, Todesco A, et al. Cancer mortality and incidence of mesothelioma in a cohort of wives of asbestos workers in Casale Monferrato, Italy. Environ Health Persp 2007;115:1401.

15 World Health Organisation. Manual of the International Statistical Classification of Diseases, Injuries, and causes of death. Geneva: World Health Organisation, 1977:49-773.

16 Marinaccio A. Registro Nazionale Mesoteliomi. In Marinaccio A, ed. Quarto Rapporto. Roma: Instituto Superiore per la Prevenzione e la Sicurezza del Lavoro, 2012

17 Musk A, De Klerk NH, Ambrosini G, et al. Vitamin A and cancer prevention I: observations in workers previously exposed to Asbestos at Wittenoom, Western Australia. Int J Cancer 1998;75:355-61.

18 Threlfall TJ, Thompson JR, Olsen N. Cancer in Western Australia: incidence and mortality 2003 and Mesothelioma 1960-2003. Perth: Department of Health, Western Australia, 2005.

19 Leigh J, Driscoll T, Hendrie L. The Incidence of Mesothelioma in Australia 1996to 1998. Australian Mesothelioma Register Report 2001. Canberra: National Occupational Health and Safety Commission, 2001

20 Stata Statistical Software: Release 12 [program]. College Station, TX: StataCorp LP, 2011.

21 de Klerk N, Musk A, Williams V, et al. Comparison of measures of exposure to asbestos in former crocidolite workers from Wittenoom Gorge, W. Australia. Am J Ind Med 1996;30:579-87.

22 Broaddus VC, Everitt JI, Black B, et al. Non-neoplastic and neoplastic pleural endpoints following fiber exposure. J Toxicol Environ Health B 2011;14: 153-78.

23 Andrion A, Magnani C, Betta P, et al. Malignant mesothelioma of the pleura: interobserver variability. J Clin Pathol 1995:48:856-60.
24 Betta P-G, Andrion A, Donna A, et al. Malignant mesothelioma of the pleura. The reproducibility of the immunohistological diagnosis. Pathol Res Pract 1997;193:759-65.

25 Metintas M, Hillerdal G, Metintas S. Malignant mesothelioma due to environmental exposure to erionite: follow-up of a Turkish emigrant cohort. Eur Respir J 1999:13:523-6.

26 Reid A, Heyworth J, de Klerk NH, et al. Cancer incidence among women and girls environmentally and occupationally exposed to blue asbestos at Wittenoom, Western Australia. Int J Cancer 2008;122:2337-44.

27 Wagner JC, Berry G, Skidmore JW, et al. The effects of the inhalation of asbestos in rats. Br J Cancer 1974;29:252-69.

28 Du Toit RS. An estimate of the rate at which crocidolite asbestos fibres are cleared from the lung. Ann Occup Hyg 1991;35:433-8.

29 Berry G. Models for mesothelioma incidence following exposure to fibers in terms of timing and duration of exposure and the biopersistence of the fibers. Inhal Toxicol 1999;11:111-30.

30 Berry G, Pooley F, Gibbs A, et al. Lung fiber burden in the Nottingham gas mask cohort. Inhal Toxicol 2009;21:168-72.

31 Helland $\AA$, Solberg S, Brustugun OT. Incidence and survival of malignant Pleural Mesothelioma in Norway: a population-based study of 1686 cases. J Thorac Oncol 2012;7:1858-61.

32 Stayner L, Welch LS, Lemen R. The Worldwide pandemic of asbestos-related diseases. Annu Rev Publ Health 2013;34:205-16.

33 Jane Henley S, Larson TC, Wu M, et al. Mesothelioma incidence in 50 states and the District of Columbia, United States, 2003-2008. Int J Occup Environ Health 2013;19:1-10.

34 Reid A, Franklin P, Olsen $\mathrm{N}$, et al. All-cause mortality and cancer incidence among adults exposed to blue asbestos during childhood. Am J Ind Med 2013:56:133-45.

\section{SCADDING-MORRISTON DAVIES JOINT FELLOWSHIP IN RESPIRATORY MEDICINE 2015}

This fellowship is available to support visits to medical centres in the U.K. or abroad for the purpose of undertaking research or training related to respiratory medicine. Applications are invited from medical graduates practising in the UK, including consultants. There is no application form. Applications should include: curriculum vitae; a detailed account of the duration and nature of the work, the role of the applicant in this work and intended benefits to the individual or UK medicine; details of the centres to be visited, and their confirmation that they have agreed to provide the facilities required; a detailed breakdown of funding requested which may include travel and subsistence. Applications lacking the required information may fail to be considered further or marked down. A sum of up to $£ 20,000$ can be awarded to the successful candidate, or the sum may be divided to support two or more applicants. Applications should be sent to the Secretary, Dr Neil McAndrew, by 31 January 2015.

Dr N McAndrew

Consultant Respiratory Physician

Wrexham Maelor Hospital

Wrexham

LL13 7TD

neil.mcandrew@wales.nhs.uk 